Practice report: Clinic, the University and Society

\title{
LAW CLINICS AND ACCESS TO JUSTICE IN KENYA: BRIDGING THE LEGAL DIVIDE
}

Yohana Ouma and Esther Chege, Strathmore University Law School, Kenya

\begin{abstract}
Despite the existence of law schools in Kenya, there has been a low uptake of clinical legal education generally and the setting up of law clinics in particular. Given the critical role that law clinics play in clinical legal education, the lack of well-established law clinics has negative implications of clinical legal education as well as the role that law schools, through law clinics, play in promoting access to justice. While the various law schools in Kenya undertake various activities that ideally fall under a law clinic, there has been a lack of institutionalization of law clinics. This has in turn limited the scope end effectiveness of the law clinics both in terms of their efforts to promote access to justice and clinical legal education. The paper argues that in order for this to be rectified, there is need to institutionalise law clinics within the various law schools in the country. Only then will they be more effective in promoting access to justice as well as clinical legal education.
\end{abstract}

\section{INTRODUCTION}

The concept of access to justice has various connotations. In common parlance, it simply refers to the accessibility or otherwise of adjudication forums where individuals can have disputes between them resolved. At a more technical level, access to justice has many 
conceptions. It may refer to the ease with which participants in the various adjudication forums are able to understand both the substantive and procedural aspects of the law applied in resolving their disputes. Access to justice may also refer to the extent to which disputants can afford the costs involved in having their disputes resolved at various adjudication forums. The above conceptions of access to justice are hardly exhaustive but only give a pointer to the breadth of the scope of access to justice. Despite this breadth, law clinics in various countries in the world have continued to engage in various activities aimed at the realization of the ideal of access to justice in its various conceptions. This paper seeks to evaluate the role played by law clinics in the realization of the ideal of access to justice in Kenya. The paper specifically uses the University of Nairobi Law Clinic as a case study to illustrate the pivotal role that law clinics play in enabling individuals to access justice. The University of Nairobi Law Clinic has been purposively selected as it is the oldest law clinic in the country. Additionally, it has largely informed the clinical legal education programmes that have been established by other law schools in Kenya. By using the University of Nairobi Law Clinic as an example, the paper also explores the untapped potential that law clinics in Kenya could harness in order to broaden and deepen their reach in promoting access to justice.

The discussion in the paper is undertaken along four major thematic areas. Part 1 of the paper operationalizes the concept of access to justice in the context of the paper. It also defines the legal divide in the context of Kenya. Part II of the paper evaluates the legal 
framework governing law clinics in Kenya. This entails a discussion of various statutes governing legal education in Kenya and more specifically, the recently enacted Legal Aid Act. ${ }^{1}$ Part III of the paper examines the overarching aim of the paper which seeks to evaluate the role of law clinics in promoting access to justice. The discussion is undertaken through an overview of the law clinic programmes in various law schools in Kenya and a case study of the Students Association of Legal Aid and Research (SALAR), the law clinic at the University of Nairobi, School of Law. The discussion covers five main areas namely the inception of the clinic, its structure, the activities it undertakes and their impact on access to justice, the impact of the clinic on employability of students and the weaknesses/ challenges of the clinic. The University of Nairobi Law Clinic has been purposively selected because it is the oldest law school in Kenya. The University of Nairobi Law Clinic is also the oldest law clinic in Kenya. An evaluation of the clinic therefore provides a sound basis for gauging the impact of the clinic in the realisation of the ideal of access to justice as well as on the employability of students. The last part of the paper suggests a way forward for law clinics in Kenya generally.

\footnotetext{
${ }^{1}$ Act no 16 of 2016.
} 
Practice report: Clinic, the University and Society

PART I: OPERATIONALISING ACCESS TO JUSTICE

While the phrase 'access to justice' has various interpretations, it would be important to operationalise the phrase in the context of the paper. On 27 th August 2010, the people of Kenya bequeathed unto themselves a new governance charter namely the Constitution of Kenya 2010. One of the key hallmarks of the 2010 Constitution is its provision for a robust and progressive Bill of Rights. The Bill of Rights in Kenya's Constitution contains various provisions that have traditionally been aimed at ensuring access to justice for individuals. Among others, these include; the fair trial rights and the rights of an accused person. However, the Constitution goes on to further specifically provide for the right of access to justice. Article 48 of the Constitution provides that the State shall ensure access to justice for all persons and, if any fee is required, it shall be reasonable and shall not limit access to justice. There are a number of deductions which can be made from this provision.

While all Kenyans are entitled to the right of access to justice, the Constitution primarily tasks the state with ensuring access to justice for all persons. In other words, one interpretation of Article 48 is that it is the responsibility of the state to take all measures to ensure that all Kenyans are able to access justice. It is also arguable that Article 48 takes cognisance of the fact that there exists a relationship between the cost of legal services and access to justice. To that extent, Article 48 tasks the state with ensuring that all 
Kenyans are able to access justice by taking steps to ensure that legal services can be accessed by all and that where any fee is required, such fee shall be reasonable and shall not impede access to justice. While the spirit of Article 48 is commendable, there is a lot that needs to be done in order to ensure that Kenyans of all walks of life are able to access justice. For instance, the Article seemingly addresses access to justice from the point of the costs involved and not necessarily legal literacy and legal awareness. Additionally, unlike other Articles in the constitution, Article 48 does not require the enacting of any Act of Parliament to give effect to it.

There are other provisions in the Constitution of Kenya 2010 which address access to justice. Article 159 of the Constitution enumerates the principles which shall guide Kenyan courts in exercising their judicial authority. These include: that justice shall be done to all irrespective of status, that justice shall not be delayed, that the courts shall promote alternative forms of dispute resolution including reconciliation, mediation, arbitration and traditional dispute resolutions and that justice shall be administered without undue regard to procedural technicalities. While these principles are aimed at promoting access to justice, it is arguable that their focus is on the courts and not necessarily the events which lead up to the courts and ultimately have a bearing on access to justice by the individuals concerned. Law clinics are often involved in both pre-court processes as well as the actual dispute resolution processes in the courts. Accordingly, a definition of access to justice as applied to law clinics must be one that captures the role 
of law clinics during the events preceding the court process as well as the adjudication of the dispute(s) in the court. As such, this paper adopts the definition of access to justice that was formulated by the Kenyan courts in the case of Dry Associates Limited v Capital Markets Authority and another. ${ }^{2}$ In the case, the court while defining access to justice stated as follows:

Access to justice is a broad concept that defies easy definition. It includes the enshrinement of rights in the law; awareness of and understanding of the law; easy availability of information pertinent to one's rights; equal right to the protection of those rights by the law enforcement agencies; easy access to the justice system particularly the formal adjudicatory processes; availability of physical legal infrastructure; affordability of legal services; provision of a conducive environment within the judicial system; expeditious disposal of cases and enforcement of judicial decisions without delay. ${ }^{3}$

This definition of access to justice is applicable in the context of this paper. The definition is rich because it captures both the events preceding the court process as well the court process itself. The definition is especially relevant with regard to law clinics. This is because the definition captures the various roles that law clinics play in the realisation of the ideal of access to justice. For instance, law clinics are involved in creating and enhancing awareness and understanding of the law and the constitutionally guaranteed

\footnotetext{
${ }^{2}$ Petition no 328 of 2011, [2012] eKLR, Para 110.

3 Ibid.
} 
rights. They are also involved in facilitating access to justice system and in making legal services affordable. Accordingly, the parameters provided by the court in the Dry Associates Limited case are used to evaluate the various activities undertaken by the University of Nairobi Law Clinic in its efforts to promote access to justice. Having operationalised access to justice in the context of the paper, it would also be important to discuss the legal divide in Kenya. The ensuing section briefly undertakes this discussion. Kenya has a population of about 42 million people, the majority of whom live on less than two dollars a day. ${ }^{4}$ The effect of this is that a significant percentage of Kenyans barely have enough resources to get by on a day to day basis. The economic disempowerment and disenfranchisement has in turn had ripple effects. These include limited access to education, even though elementary/primary level of education is free in all public primary schools. Even when children are able to make it through the eighth year elementary primary education level, many of them do not pursue their education further due to limited resources or the unavailability of resources altogether. This in turn limits the employment prospects of such individuals and in the process perpetuates the dreaded cycle of poverty. For this category of individuals, access to justice is often an unrealistic hope. They not only lack the financial resources to access the courts, but also have low or no legal literacy or awareness at all. As a result, when they suffer injustice, they are often left to their own devices, usually with little or no knowledge of where to

\footnotetext{
${ }^{4}$ See USAID website, <http://www.state.gov/documents/organization/159172.pdf > accessed 7 July 2016.
} 
seek help or even when able to seek help, they are unable to follow through the processes required so that they can ultimately have the injustices redressed.

On the other hand, individuals who have the financial ability are often able to afford legal services and thus are able to access the adjudication forums and follow through the requisite process until the injustices they suffered are redressed. Put simply, the state of access to justice in Kenya is characterised by a legal divide between the haves and the have nots. As is illustrated in the case study of the University of Nairobi Law Clinic, law clinics have played and continue to play a critical role in bridging this legal divide. It is noteworthy that at the heart of the legal divide in Kenya is the difference in availability and possession of resources between the haves and the have nots. Law clinics may not necessarily address the other factors that limit access to justice by the have nots. However, they can and do directly play a role in bridging the legal divide through undertaking various activities that are often solely aimed at promoting access to justice. Before embarking on the case study to illustrate how law clinics play this role in Kenya, it would be important to examine the legal framework governing law clinics in Kenya. The next section of the paper undertakes this discussion. 


\section{PART II: THE LEGAL FRAMEWORK GOVERNING LAW CLINICS IN KENYA}

For a long time, there has been no specific legislation governing law clinics in Kenya. This position changed recently with the enactment of the Legal Aid Act 2016, ${ }^{5}$ which although generally focused on Legal Aid, has numerous provisions addressing law clinics. This is due to the fact that law clinics are key players in providing legal aid in Kenya. It is important to state that before the enactment of the Legal Aid Act 2016, law clinics of the various law schools in Kenya were not governed by any Act of Parliament. The Legal Aid Act sought to address this by providing some requirements which will be applicable to all law clinics. It is also noteworthy that even though legal aid and access to justice have a direct correlation with each other, the two are not necessarily synonymous with each other. Legal aid is a facet of access to justice.

Law clinics are at the heart of clinical legal education. Accordingly, a discussion of the legal framework governing law clinics in Kenya would of necessity entail an examination of the legislation governing legal education in Kenya. The examination is done with a view to identifying the extent, if any, to which the legal framework governing legal education in Kenya provides for clinic legal education and as such, indirectly provide for law clinics. The paper undertakes this discussion first and subsequently reviews the Legal Aid Act.

\footnotetext{
${ }^{5}$ Act no 16 of 2016.
} 
Practice report: Clinic, the University and Society

There are two main statutes that govern legal education in Kenya namely the Legal Education Act ${ }^{6}$ and the Kenya School of Law Act. ${ }^{7}$ The preamble of the Legal Education Act states that it is intended to provide for the establishment of the Council of Legal Education, the establishment of the Legal Education Appeals Tribunal and the regulation and licensing of legal education providers and for connected purposes. It is arguable that from this preamble, the focus of the Act is on the institutions rather than the content of legal education itself. As part of regulating institutions that provide legal education, the Act requires universities that offer undergraduate law degree programmes to offer certain core courses which include: Legal Research, Law of Torts, Law of Contract, Legal Systems and Methods, Criminal Law, Family law and Succession, Law of Evidence, Commercial Law, Law of Business Associations, Administrative Law, Constitutional Law, Jurisprudence, Equity and the Law of Trusts, Property Law, Public International Law and Labour Law. ${ }^{8}$ All these are primarily theoretical courses which involve attending lectures and taking examinations at the end of the semester. As evidenced by the list above, law schools in Kenya are under no obligation to develop clinical legal education programmes.

As had already been stated earlier, establishment of law clinics is one of the main ways of developing and delivering clinical legal education. A resultant effect of the exclusion

\footnotetext{
${ }^{6}$ Act No 27 of 2012.

${ }^{7}$ Act No 26 of 2012.

${ }^{8}$ Section 23(1) as read with the Second Schedule to the Legal Education Act 2012.
} 
of clinical legal education as one of the mandatory modules that must be offered in law schools in Kenya is that clinical legal education is given little, if any priority, by many law schools. This is usually manifested by the lack of law clinics in some law schools or even where they exist, they lack the requisite support and recognition from the law school. Perhaps the scenario would have been different if the Legal Education Act had included clinical legal education as one of the modules/programmes that must be offered by law schools in Kenya.

The Kenya School of Law Act, Act No 26 of 2012

The main purpose of the Kenya School of Law Act is to provide for the establishment of the Kenya School of Law which is primarily tasked with offering a one and half year's advocates' training programme that prepares law graduates from universities to become advocates of the High Court of Kenya. Generally, one can only be admitted to the roll of advocates in Kenya after completing both an undergraduate law degree and the one and half year training at the Kenya School of Law. The Act empowers the Board of the School to determine and publish in the Kenya Gazette the academic programmes in the school and the course units. ${ }^{9}$ Over the years, clinical legal education has not been incorporated as one of the academic programmes at the school. However, the school undertakes, as extra-curricular activities, various initiatives which fall under the scope of clinical legal education. The main activity is legal aid clinics that are held in various prisons across the

\footnotetext{
${ }^{9}$ Section 18 of the Kenya School of Law Act.
} 
country. ${ }^{10}$ Participation in the prison legal aid clinics is open to all students who volunteer to take part in the clinics. The upshot of the foregoing discussion is that the 'law clinic' programme at the Kenya School of Law can hardly be said to have been institutionalised. At best, it can only be termed as corporate social responsibility by the school. This in itself is not a criticism but a contention that perhaps with the institutionalisation of the clinic, it would be able to play a bigger role in promoting the ideal of access to justice.

The Legal Aid Act, No 6 of 2016

The Legal Aid was enacted in 2016 as part of the efforts to promote access to justice in Kenya through the provision of legal aid. The Act has a number of provisions which directly affect the law clinics of various law schools in Kenya. The preamble to the Legal Aid Act notes that one of the reasons for its enactment is to give effect to Article 48 of the Constitution. It further broadly defines legal aid to inter alia, include: legal advice, legal representation, creating awareness through the provision of legal information and law related information and recommending law reform and undertaking advocacy work on behalf of the community. This definition encompasses most of the activities that are undertaken by law clinics in various law schools in the country. It is therefore a welcome development that the activities which are undertaken by the various law clinics have been given statutory recognition under the Act.

\footnotetext{
${ }^{10}$ See Kenya School of Law website, <http://www.ksl.ac.ke/index.php/academic-programmes-courseofferings/advocates-training-programme?start=5> accessed 7 July 2016.
} 
The Act covers law school clinics under legal aid providers. It specifically provides that 'legal aid provider' among others means a university or other institution operating legal aid clinics. ${ }^{11}$ The Act also establishes the National Legal Aid Service whose mandate is generally to broaden and deepen legal aid initiatives and in the process, promote access to justice. ${ }^{12}$ The National Legal Aid service is also tasked with liaising with the Council of Legal Education in the development of programmes for legal aid education. ${ }^{13}$ Additionally, the Service has the mandate to promote and supervise the establishment and working of legal aid services in universities, colleges and other institutions. ${ }^{14}$ These provisions may significantly alter the landscape as far as law clinics and clinical legal education in Kenya is concerned. This assertion is informed by a number of reasons. First, unlike previously where law clinics of various universities were established and operated independently of each other and had no external oversight, under the Act, the National Aid Service will exercise supervisory powers over the various law school clinics. Secondly, the Act arguably contemplates that for legal aid to take root in the country, there is need for a more robust programme of clinical legal education in the various universities that offer legal training. Accordingly, the Service is tasked with the development of programmes for legal aid education. It is submitted that if these programmes are well developed, law schools in Kenya may well be on course to reaching

\footnotetext{
${ }^{11}$ Section 2 of the Legal Aid Act.

${ }^{12}$ Section 5 of the Legal Aid Act.

${ }^{13}$ Section 7 of the Legal Aid Act.

${ }^{14}$ Section 7 of the Legal Aid Act.
} 
the heights of clinical legal education that have been attained by law schools in the world which have reputable clinical legal education programmes.

One of the key hallmarks of the Act is its provision for a Legal Aid Fund. ${ }^{15}$ The monies of the Fund may be applied in meeting the expenses of legal aid providers in providing services. ${ }^{16}$ This is a welcome development particularly due to the fact that inadequate or a complete lack of resources has hindered the programmes of many law clinics. If the Legal Aid Fund is well utilised, law clinics in Kenya will be better placed to be more effective in providing legal aid. The Fund may enable them attain some level of selfdependency and sufficiency as opposed to the present situation where they are forced to adopt a primarily collaborative approach in the provision of legal aid services. While the collaborative approach is not necessarily bad, it has had the effect of limiting the scope of the activities of the law clinics. This is because often, it is the partners of the law clinics who determine the kind of programmes the law clinic will be involved in. One can only hope that in disbursing monies to law clinics, the National Legal Aid Service will not attach very stringent conditions that will have the effect of limiting the scope of services provided by law clinics. However, it is also important to state that the monies of the Fund will not be restricted to only law school clinics but will also be disbursed to other legal

\footnotetext{
${ }^{15}$ See generally Part V of the Act.

${ }^{16}$ Section 30 of the Legal Aid Act.
} 
aid providers. As such, it remains to be seen what portion of the Fund will be allocated to the law clinics of various law schools in the country.

Another key feature of the Act is the requirement for accreditation of legal aid providers. ${ }^{17}$ Unlike previously where law clinics in various law schools were able to provide legal aid services without the requirement of being licensed by any authority, under the Legal Aid Act 2016, institutions and organisations will only provide legal aid services after they have been accredited by the National Legal Aid Service. The Service is also empowered to develop the accreditation criteria which it will use in accrediting various legal aid providers. Accreditation may have both negative and positive effects. The positive effect may flow from the fact that recipients of legal aid from the various legal aid providers will be in a position to ascertain that they are receiving legal aid from legitimate and duly accredited legal aid providers. This will turn enhance the confidence of the public in the legal aid providers. However, from previous experience of various accreditation processes in Kenya, there are two key challenges that may flow from the accreditation requirement.

First is the fact that often, the fees for accreditation are usually very steep. In the event that the National Legal Aid Service sets the fees for accreditation of legal education providers at unusually high levels, the Service will be going against the principal reason for which it was established, namely to promote access to justice through broadening and

\footnotetext{
${ }^{17}$ See generally Part VIII of the Legal Aid Act.
} 
deepening legal aid in Kenya. High accreditation fees may serve as an entry barrier for law school clinics which seek to provide legal aid services. This is due to the limited resources that most law schools in the country have.

Unless law clinics are a key priority for law schools in the country, it is arguable that unreasonably high accreditation fees may lead to the collapse of the nascent law clinics in various law schools in Kenya. The second challenge that flows from the accreditation requirements is that often the accreditation process takes a long time. This may in turn limit or altogether stop the activities of the law clinics as they await accreditation. Limitation of the activities of law clinics will in turn curtail their role in promoting access to justice. As such, it is imperative that the accreditation requirements and process is handled carefully so as to encourage more players, and particularly law schools to establish law clinics and promote clinical legal education. If not handled carefully, the accreditation requirements and process may have the opposite effect of limiting access to justice and eroding the little gains that have been made in promoting access to justice through provision of legal aid.

Overall, the enactment of the Legal Aid Act is a welcome development. This is because the Act is in keeping with the ideal of promoting access to justice as enshrined in Article 48 of the Constitution. However, it remains to be seen whether the manner of implementation of the Act will ultimately promote access to justice. 
Practice report: Clinic, the University and Society

Having defined access to justice, the legal divide and discussed the legal framework governing law clinics in Kenya, the next section of the paper gives a brief overview of the clinical legal education programmes of various law schools in Kenya. This is then followed by the case study of SALAR, the law clinic at the University of Nairobi School of Law.

PART III: LAW CLINICS AND ACCESS TO JUSTICE IN KENYA: OVERVIEW OF VARIOUS CLINICAL LEGAL EDUCATION PROGRAMMES IN KENYA According to the Council of Legal Education of Kenya, there are eight accredited law schools in Kenya. ${ }^{18}$ It is noteworthy that of the eight, seven were established from the year 2012. Two other law schools which are not in the current list of accredited law schools were established in the pre-2012 period. These are the Moi University Law School established in 1994 and the Catholic University of Eastern Africa Law School established in 2005. Accordingly, in terms of years of existence, the University of Nairobi Law School is the oldest, followed by the Moi University Law School and the Catholic University of Eastern Africa Law School.

Of the three law schools that were established before the year 2012, only the University of Nairobi School of Law and the Moi University School of Law have law clinics. The

\footnotetext{
${ }^{18}$ See Council of Legal Education Website, <http://www.cle.or.ke/status-of-universities/> accessed 10 October 2016.
} 
Catholic University of Eastern Africa Law School has no law clinic per se but from time to time undertakes various activities which ideally fall under the ambit of a law clinic. This includes organizing law clinics in prisons and legal awareness and sensitisation campaigns. Most of the law schools established in the post 2012 period have adopted a similar approach where they do not have law clinics but instead organize various activities that ideally fall under the ambit of a law clinic. For instance, at the Kabarak University School of Law, the law clinic is one of the programmes that is run by the law students' association, the Kabarak University Law Students Association (KULSA). ${ }^{19}$ The main activities undertaken in the programme include holding law clinics in prisons and in the environs of the law school.

At the Kenyatta University School of Law, there is no established law clinic but there are various activities which fall under the ambit of a law clinic. ${ }^{20}$ The main activity is the Public Interest and Awareness Programme. ${ }^{21}$ This is a student led initiative which entails hosting law clinics in various parts of the country.2. It is, however, important to note that while the programme is student led, various Non-Governmental Organisations (NGOs) play a key role to ensure the successful realisation of the programme. It is more of a

\footnotetext{
${ }^{19}$ See <http://law.kabarak.ac.ke/kulsaprogrammes.php> accessed 10 October 2016.

${ }^{20} \mathrm{See}<\mathrm{http} / / /$ law.ku.ac.ke/index.php/component/content/article/97-school-news/169-legal-aid-awareness> accessed 10 October 2016.

${ }^{21}$ Ibid.

${ }^{22}$ Ibid.
} 
partnership between the law school and the various NGOs rather than an independent, self-sustaining programme run by the law school.

Moi University Law School is perhaps the only law school in Kenya which right from establishment, sought to institutionalise clinical legal education. Accordingly, the legal aid department is one of the four departments in the law school. ${ }^{23}$ The school emphasizes a clinical approach to learning which is anchored in the Moi University Legal Aid Clinic (MULAC). ${ }^{24}$ The clinical legal education is delivered through simulation and live-client representation of indigent clients with a focus on children matters. However, though this is the ideal model that the paper advocates for, it was also heavily dependent on an external advocate who was the key resource person for the clinic. ${ }^{25}$ Once the advocate left the clinic in 2014, all the activities of the clinic ground to a halt. ${ }^{26}$ This points to the fact that although the clinic was conceptualised as a self-sustaining clinic, its success was largely dependent on the availability of funds to enable it retain staff such as advocates who would take up deserving matters.

Strathmore Law School is also in the process of setting up its law clinic. During its four years of existence, it has undertaken various clinic activities in collaboration with various NGOs. Egerton University Law School is barely a year old. At present, it does not have a

\footnotetext{
${ }^{23} \mathrm{See}<$ https://law.mu.ac.ke/index.php/departments/legal-aid-clinic\#the-department-and-the-school $>$ accessed 10 October 2016.

${ }^{24}$ Ibid.

${ }^{25}$ Interview with Kevin Koome, an immediate former student of the Moi University School of Law who graduated in the year 2015. Koome was a student at Moi University Law School when the Clinic was still active and subsequently during the period of its decline.

${ }^{26}$ Ibid.
} 
Practice report: Clinic, the University and Society

law clinic. Having provided a brief overview of the various approaches to clinical legal education generally and law clinics in particular in law schools in Kenya, the next session delves into an in depth discussion of the law clinic at the University of Nairobi Law School where the author served as the student chairperson during the academic year 2014-2015.

A Case Study of the Students Association for Legal Aid and Research (SALAR)

The Students Association for Legal Aid and Research (SALAR) is the law clinic at the University of Nairobi, School of Law. The University of Nairobi, School of Law was established in 1970 but it was not until 2002 that the law clinic was established. SALAR was conceptualised and birthed through the efforts of Ms. Joy Asiema, a law lecturer at the University of Nairobi and the current patron of the association and Prof. Loiuse McKinney, then of the Milton Kramer Law Clinic at Case University School of Law. ${ }^{27}$ Right from the outset, SALAR was not institutionalised as one of the key centres of the University of Nairobi School of Law. On the contrary, it was founded as club or society where students could undertake extra-curricular activities through provision of legal aid services. Accordingly, flowing from the fact that it is an association/club, membership of SALAR is voluntary and open to all law students at the University of Nairobi upon

\footnotetext{
${ }^{27}$ See SALAR website, <http://www.uonsalar.org/web/research_publications/SALAR\%20PROFILE\%20(2).pdf> accessed 7 July 2016.
} 
payment of a membership fee of Kshs 200 (approximately 2 USD). The fee is payable each semester. During the author's time as the chairperson of the association, SALAR had a membership of about 200 students from a student population of 1500 students at the University of Nairobi, School of Law. The funds raised from the membership fees are primarily used to run the activities of the association. It is arguable that the lack of institutionalisation is what led to the mixed fortunes of SALAR over the years with regards to its efforts to promote access to justice.

SALAR has four principal objectives namely: to provide free legal services to persons who cannot afford to pay for legal services, to inculcate a public interest lawyering spirit in law students and build on that spirit as a basis for the creation of responsible legal professionals, to promote and undertake legal research as a key component of legal education and lastly, to establish and develop links with governmental institutions, nongovernmental organisations and lawyers with the aim of promoting and expanding the scope of social justice. ${ }^{28}$ SALAR lists its key areas of legal assistance to include: matrimonial disputes and children matters, human rights violations, land disputes, succession and inheritance and employment and labour disputes. From the author's experience of three years as a member of SALAR and one year as the chairperson of the association, the areas of legal assistance by SALAR were largely determined by the 
Practice report: Clinic, the University and Society

partner organisations which collaborated with SALAR. The discussion on this is revisited in later sections of the paper.

SALAR has a three tier organisational structure. At helm of SALAR's organisational structure is the supervisory board. The supervisory board is composed of at least three members but not more than five members of faculty of the University of Nairobi, School of Law and/or practising advocates. The function of the of the supervisory board is limited to playing an advisory role in terms of ensuring that all the activities of the Association are carried out in accordance with the constitution of the Association as well the custom and practice of the legal profession. The supervisory board is also tasked with ensuring that the activities and policies of the Association do not violate the laws of Kenya.

Below the supervisory board is the Steering Committee. This is a body of students that is tasked with running the day to day activities of the Association. The Steering Committee is comprised of six members namely; the chairperson, the vice-chairperson, the secretarygeneral, the organising secretary, the treasurer and the librarian. Lastly, are the members of the Association who complete the last part of the three tier organisational structure. There are a number of observations that can be made from the above discussion on the profile of SALAR especially with regard to its efforts to promote access to justice. First is the fact that it is not properly institutionalised within the structures of the School of Law and is considered a students' club or society which students form to engage in extra- 
curricular activities. Put differently, while SALAR's activities fall under the ambit of clinical legal education, the University of Nairobi School of Law just like most law schools in Kenya is yet to fully institutionalise clinical legal education. Second, it is noteworthy that the association relies on membership fees to run its activities. The funds raised from membership fees are hardly ever adequate to enable the Association undertake the various activities aimed at promoting access to justice. Consequently, the Association primarily relies on activities it undertakes in collaboration with various partners so as to promote the ideal of access to justice. Third and perhaps more worrying, the fact that the law clinic was founded almost over 30 years after the establishment of the law school arguably points to the low priority accorded to law clinics and clinical legal education in Kenya. However, it is commendable that after the establishment of SALAR, various universities that have since established law schools have not taken such a long duration to establish law clinics or to come up with various activities that usually fall under the ambit of a law clinic. The lack of institutionalisation of law clinics, however, is still a persisting problem.

Activities of SALAR in its efforts to promote access to justice

Despite the various shortcomings, SALAR has over the years undertaken various activities that are aimed at promoting access to justice. It is, however, important to note that most of these activities have been undertaken in collaboration with partners rather than on SALAR's own initiative. A number of activities could be used illustratively. 
SALAR has a long running partnership with Kituo Cha Sheria, a local NGO involved in providing free legal services to the unserved and the underserved. Kituo cha Sheria usually organises monthly legal aid clinics in which SALAR members participate in giving free legal aid to members of the public. Cases which require to be taken to court are subsequently taken up by Kituo cha Sheria and the students provide research assistance during the subsistence of the case. Kituo cha Sheria also organises legal awareness campaigns in the informal settlements and slums. SALAR members are usually heavily involved in these legal awareness and sensitisation programmes. In late 2014 and early 2015, SALAR, through a partnership with the Kenya Human Rights Commission (KHRC), a local NGO, held legal aid clinics in ten out of the 47 counties in Kenya. Kenya Human Rights Commission handled all the logistics for the clinics while SALAR's members conducted the actual clinics in the various counties. The students were always accompanied by personnel from Kenya Human Rights Commission who would oversee their work. Kenya Human Rights Commission would then take up the deserving cases where the concerned individuals required legal assistance to initiate judicial proceedings. SALAR also has a long running partnership with the Kenya Human Rights Commission where a number of its members attend and participate in the legal aid clinics that are held at the Kenya Human Rights Commission Offices at the last Saturday of every month. SALAR also has a number of similar partnerships with other organisations that seek to promote access to justice. Some of the organisations include 
Amnesty International-Kenya Chapter, the International Justice Mission-Kenya Chapter, the Kenya Red Cross Society among others. The upshot of the foregoing is that SALAR has primarily relied on a partnership model to promote access to justice. This has had its inherent weaknesses but has nevertheless, not deterred the clinic from having an impact on access to justice in Kenya as well as on the members of the clinic itself.

\section{The Impact of the Clinic}

The discussion on the impact of the clinic is undertaken under two broad strands namely the impact of the clinic on access to justice generally and the impact of the clinic on the employability of students. Through various collaborations, SALAR has been able to play a small but significant role in helping realise the idea of access to justice. This has been particularly through the legal awareness and sensitisation campaigns through which the association has been able to reach out to large segments of the population, especially the unserved and the underserved. Additionally, during the clinics, there were numerous cases where the matters presented by members of the public were resolved through the advice given at clinics and did not require to be taken up to court. SALAR has also played a key role in enabling partner organisations reach and provide free legal services to members of the public.

Membership and participation in SALAR's activities has also played a key role in enhancing the employability of its members. A number of examples could be used illustratively. The author's involvement in the activities of the clinic was instrumental in 
his getting employment at the Strathmore University Law School immediately after completing his undergraduate studies at the University of Nairobi School of Law. Similarly, one of the leading law firms in Kenya directly got in touch with the leadership of SALAR and asked for applications for students who would be interested to work in the law firm. The process culminated in the employment of one member of SALAR in the leading law firm, leading to her completing her studies while already with a job in hand. The Kenya Human Rights Commission, (KHRC), has also consistently given preference to SALAR members when conducting its recruitment. Due to the lack of proper records on the career path of SALAR members, it is difficult to exactly tell how many of them have been able to have a competitive edge in recruitment processes of various organisations, both governmental and non-governmental. However, anecdotal evidence points to a strong correlation between membership and participation in the law clinic's activities and increased chances of employability.

The last part of paper critiques the SALAR model of the clinic and offers suggestions on the way forward.

\section{PART IV: TOWARDS GREATER AUTONOMY/ A SELF-SUSTAINING MODEL}

While SALAR and indeed other law clinics in Kenya have been able to play a significant role in promoting access to justice, it is arguable that for them to have a greater impact, the law clinics must increase their autonomy and avoid solely relying on partnerships 
with other like-minded organisations. Where this happens, then SALAR as well as other law clinics will be in a position to host their own internal walk in clinics within the law schools rather than solely relying on partners. Consequently, the law clinics will be in a position to reach more people and provide the much sought legal aid services that many cannot afford. However, for the greater autonomy to be successfully realised, there is need fully institutionalise law clinics within the set-up of law schools in Kenya rather than having them as part of clubs and societies which students join to engage in extracurricular activities during their free time. Law clinics are at the heart of clinical legal education. The importance of clinical legal education to a lawyer cannot be understated. Consequently, for there to be robust law clinics in Kenya as well a robust clinical legal education programme, there is need for a paradigm shift to move away from the current model to a model where law clinics are fully institutionalised and clinical legal education forms part and parcel of the legal education of law students.

\section{CONCLUSION}

From the preceding discussions, the paper concludes that while law clinics in Kenya, as illustrated by the example of SALAR, play a significant role in the promoting access to justice, there is more that needs to be done to enable law clinics in Kenya claim their rightful position in the promotion of access to justice. The paper concludes that a sure first step in the realisation of this goal may well lie in the institutionalisation of law clinics. 
The challenge is, therefore, on the various law schools to take a leading and active role in ensuring that they establish, and where already established, they institutionalise their law clinics and give them the requisite support to enable them effectively play their role of promoting access to justice. 